\title{
Human Cancer Models Initiative
}

National Cancer Institute

\section{Source}

National Cancer Institute. Human Cancer Models Initiative. NCI Thesaurus. Code C134624.

A collaboration between the National Cancer Institute, Cancer Research UK, the Wellcome Trust Sanger Institute, and the foundation Hubrecht Organoid Technology to generate new models of cancer that more accurately represent human tumors than existing cell line models. 